\title{
Analysis of Campus Recruitment Parameters in an Indian Context
}

\author{
Dr. V.Samuel Rajkumar \\ Director(Placement and Training), VIT University, Vellore, Tamil Nadu, India \\ Email:sam.rajkumar@vit.ac.in
}

\section{Dr. R. Prabhakara Raya}

Head, Department of Management Studies, Pondicherry University, Pondicherry, India

Email:drrpraya@gmail.com

\section{Dr. P. Ganesan}

Professor, VIT Business School, VIT University, Vellore, Tamil Nadu, India

Email: pganesan@vit.ac.in

\section{Dr. S.K.V. Jayakumar}

Placement Co ordinator, Pondicherry University, Pondicherry, India Email: skvjey@gmail.com

\section{Doi:10.5901/mjss.2015.v6n5p62}

\section{Abstract}

Campus recruitment is the process by which the corporate recruit students who are about to graduate from the educational institutions. The selection process varies from company to company, may have pre placement talk, written test, group discussion and interviews. Students and the recruiting companies are considered to be the major stake holders in a campus recruitment process. Entry level salaries and the recruitment season are considered to be the important parameters in a campus recruitment process. The study analyses the perception of the students and the human resources (HR) managers on the entry level salaries and the recruitment season.

Keywords: Campus recruitment, recruitment season, salary

\section{Introduction}

Campus recruitment is considered to be one of the major parameter by a parent in making his / her ward getting admitted into an educational institution in India. In order to attract good talent for admissions or research an educational institution has to position itself among the corporate. Various branding activities are done by the institutions to attract MNC ${ }^{1}$ companies for domestic and international recruitments and academic collaborations. The reputation of any professional educational institution in the country is measured by the collaborations it has with the industry in terms of recruitment, research, academic and non academic collaborations.

The selection process takes place in the final year of a programme for students of both undergraduate and post graduate courses. In India, most of the fresher engineering talent hiring happens through the campus recruitments, out of which, majority of the campus hiring is done by the $\mathrm{IT}^{2}$ and $\mathrm{BPO}^{3}$ sector. According to NASSCOM ${ }^{4}-2012$ report the IT and BPO industry continues to be the major employment generator in India adding more than 2,30,000 jobs in India for the year 2012. The sector had provided 2.8 million direct jobs and 8.9 million indirect jobs.

In addition to the IT and BPO sector companies, fresh engineers are also sought and hired by the core engineering

\footnotetext{
${ }^{1}$ Multinational companies

2 Information Technology

${ }^{3}$ Business process outsourcing

${ }^{4}$ National Association of Software and Services companies
} 
companies, but in small numbers compared to the hiring done by the IT and ITES ${ }^{5}$ sector. According to a study conducted by TimesJobs.com (2013), approximately 70 to 80 per cent graduates' recruitment is done through campus recruitments. Though there are other sciences and professional programmes in the country, students pursuing engineering courses are considered to be the major target audience in campus recruitments.

\section{Literature Survey}

Campus recruitment is considered to be a significant factor for both the educational institutions and corporate. The literatures investigated show that there is a mismatch that exist between the students skills and the industry expectations. There are various factors that influence a student to attract him or her for a job offered by a company. More than the technical skills and the subject knowledge, it is the soft sill which is given more weightage during the campus recruitment process. The industry in order to get good talent from the campuses should engage themselves with the campuses through internships, curriculum development, student workshops etc., The studies emphasize the characteristics of campus recruitment process.

The decision of engineering students in making their first career choice depends mostly on intrinsic reasons rather than extrinsic reasons (Gokuladas, 2010). In India, the software services companies are the major campus recruiters. They recruit from all engineering branches with a perception that a student with logical and problem - solving ability may be able to do well in this industry. The study conducted reveal that the companies have to build their image on the campuses to attract good talent. The brand image of the company is considered as a prime influencing dimension by the non - computer science / IT students in making their career choice when they have an option of choosing among multiple companies.

Bruce Basta, D' Archy Becker, P.Jane Staly, Richard S Sathe and Kate Mooney (2007), through their study have opined that the campus recruitment process should be not considered as a onetime recruitment process. It should be considered as an ongoing process. The corporate instead of visiting all the campuses, should identify some reputed campuses and brand themselves. If there are not much recruitments happening during an year, the corporate should engage the identified campuses through branding activities like Guest lectures, student workshops, sponsorships etc.,

The objective of the study is to analyse the perceptions of the students and the HR managers with regard to the two of the important parameters in campus recruitment process namely, (a) campus recruitment season and (b) campus hiring salary. The said parameters were analysed by framing the following hypotheses:

$H I$ : The opinion of HR managers and students is same with respect to campus recruitment season.

H2: The opinion of the HR managers and students in expectations on campus hiring salaries is same.

\section{Methodology}

In order to study the objective of the study and to test the stated hypotheses, descriptive research approach is followed in this study. VIT University, a Deemed University located in Tamil Nadu, India was chosen as a unit for the study. Students and the human resources managers who are the major stake holders in a campus recruitment process were chosen as the sampling units. Based on the earlier literature and expert opinion (industry and academics), an instrument was developed and tested empirically. The population of the study consisted of $172 \mathrm{HR}$ managers from various industries who have visited VIT in the past for campus recruitments. Stratified random sampling method was used to stratify the HR managers into two groups namely, core engineering and software sectors. A sample size of 86 HRs (50 per cent of the population) was fixed. The random number generation process (through MS-excel) of simple random sampling method was applied to select $43 \mathrm{HR}$ managers from each sector. Repeated reminders through phone and email were given to respondents till the sample size crossed 25 per cent of the population. After removal of questionnaires with missing data, 65 sample respondents were chosen for the analysis, of which, 39 of them were from IT sector and 26 from core engineering sector. The analysis is presented for the $65 \mathrm{HR}$ sample, not sector-wise.

Final year students of VIT University, who were considered to be another stake holder in a campus recruitment process, were chosen for the study. A total of 2598 final year students were listed. A sample size of 1299 students (50 per cent of the population) was fixed, out of 2598 final year students. The random number generation process (through MS-excel) of simple random sampling method was used to identify the 1299 respondents. A total of 760 responses were received and after data cleaning, a total of 697 usable questionnaires were used for the analysis.

After coding and validating, the responses were analysed using statistical tools like frequencies and Chi square

${ }^{5}$ Information Technology enabled service 
test is used to test the hypotheses.

\section{Analysis of Campus Recruitment Season}

The table shows the perceptions of the students and HR managers on the ideal campus recruitment months.

Table 4.1. Ideal period for campus recruitment process

\begin{tabular}{|c|c|c|c|c|c|c|c|}
\hline \multicolumn{7}{|c|}{ Group * Month Cross tabulation } \\
\hline & & & \multicolumn{3}{c|}{ Month } & \multirow{2}{*}{ Total } \\
\hline & & & June / July & August / September & October/ November & After January & The \\
\hline \multirow{4}{*}{ Group } & Students & Count \% & 51 & 401 & 180 & 65 & 697 \\
& $(N=697)$ & within Group & $(7.3)$ & $(57.5)$ & $(25.8)$ & $(9.3)$ & $(100)$ \\
\cline { 2 - 8 } & HR Managers & Count \% & 9 & 26 & 21 & 9 & 65 \\
& $(N=65)$ & within Group & $(13.8)$ & $(40)$ & $(32.3)$ & $(13.8)$ & $(100)$ \\
\hline
\end{tabular}

Table 4.1 shows that 57.5 per cent of the students feel that August and September as the ideal period and 25.8 per cent feel that October and November as ideal months for the campus placement process. With respect to the HR managers, 40 per cent of them were of the opinion that August and September as the ideal months for the recruitment, where as 32.3 per cent of them stated the October - November.

Table 4.2. Analysis of campus recruitment season - Chi square test

\begin{tabular}{|c|c|c|c|}
\hline \multicolumn{4}{|c|}{ Chi-Square Tests } \\
\hline & Value & Df & Asymp. Sig. (2-sided) \\
\hline Pearson Chi-Square & $8.678^{\mathrm{a}}$ & 3 & .034 \\
\hline a. 0 cells (.0\%) have expected count less than 5. The minimum expected count is 5.12. \\
\hline
\end{tabular}

Both the HR Managers and the students are not of the same opinion on the campus recruitment season, this is supported by the chi square tests (Value=8.678; $\mathrm{Sig}=0.034)$. Hence, hypothesis $(\mathrm{H} 1)$ is not accepted.

\subsection{Analysis of salary expectations}

The Table 4.3 shows the perceptions of the students and HR managers on the perceptions of students and HR managers on compensation/salary to be offered to the campus recruits.

Tables 4.3 and 4.4 present the frequency and chi square test analysis on compensation component in campus recruitment.

Table 4.3. Analysis of salary expectations - frequencies

\begin{tabular}{|c|c|c|c|c|c|c|c|}
\hline \multicolumn{8}{|c|}{ Group * Range of Salary Cross tabulation } \\
\hline & & & \multicolumn{4}{|c|}{ Range of Salary } & \multirow[b]{2}{*}{ Total } \\
\hline & & Salary range & $\begin{array}{l}\text { Rs. } 3.51 \text { lakh \& } \\
\text { above }\end{array}$ & $\begin{array}{c}\text { Rs. } 3.11 \text { lakh - Rs. } 3.50 \\
\text { lakh }\end{array}$ & $\begin{array}{c}\text { Rs. } 2.81 \text { lakh - Rs. } 3.10 \\
\text { lakh }\end{array}$ & $\begin{array}{c}\text { Rs. } 2.4 \text { lakh - Rs. } 2.80 \\
\text { Lakh }\end{array}$ & \\
\hline \multirow[b]{2}{*}{ Group } & $\begin{array}{l}\text { Students } \\
(\mathrm{N}=697)\end{array}$ & \begin{tabular}{|c|} 
Frequency \\
(percentage)
\end{tabular} & $\begin{array}{l}544 \\
(78)\end{array}$ & $\begin{array}{c}126 \\
(18.1)\end{array}$ & $\begin{array}{c}19 \\
(2.7)\end{array}$ & $\begin{array}{c}8 \\
(1.1)\end{array}$ & $\begin{array}{c}697 \\
(100)\end{array}$ \\
\hline & $\begin{array}{c}\mathrm{HR} \\
(\mathrm{N}=65)\end{array}$ & $\begin{array}{c}\text { Frequency } \\
\text { (percentage) }\end{array}$ & $\begin{array}{c}30 \\
(46.2)\end{array}$ & $\begin{array}{c}21 \\
(32.3)\end{array}$ & $\begin{array}{c}12 \\
(18.5)\end{array}$ & $\begin{array}{c}\frac{1}{2} \\
(3.1)\end{array}$ & $\begin{array}{c}65 \\
(100)\end{array}$ \\
\hline
\end{tabular}

Table 4.3 shows the respondents expectations on entry level salary ranges. The software services companies in India have not increased the entry level salaries for more than 5 years. The average salary per annum offered by the top 5 software services companies (Accenture, Cognizant, Infosys, TCS $^{6}$ and Wipro) range between INR 2.75 and INR 3.36 lakhs per annum for under graduate students and between INR 2.75 lakhs and INR 3.63 lakhs for post graduate students.

\footnotetext{
6 Tata Consultancy Services

${ }^{7}$ Indian Rupees
} 
Core Engineering companies also have not increased the salary substantially. It ranged from INR 2.5 lakhs to 3.5 lakhs per annum

78 per cent of the students feel that the entry level salary should be INR 3.5 lakhs per annum. 46.2 per cent of the HR managers suggest that the entry salaries should be above INR 3.51 lakhs per annum.

Table 4.4. Analysis of salary expectations - chi square test

\begin{tabular}{|c|c|c|c|}
\hline \multicolumn{4}{|c|}{ Chi-Square Tests } \\
\hline & Value & df & Asymp. Sig. (2-sided) \\
\hline Pearson Chi-Square & $52.143^{\mathrm{a}}$ & 3 & .000 \\
\hline
\end{tabular}

Chi square tests revealed (table 4.4) that there was significant difference (Value $=52.43$; Sig $=0.000$ ) in the perceptions of the two stake holders (HR managers and students) in terms of the salary expectations. Hence, hypothesis $(\mathrm{H} 2)$ is not accepted as there was no relationship in the opinion among the HR managers and students regarding the salary expectations.

\section{Findings and Conclusion}

There has been always confusion between the industry and the educational institutions in finding out the right season for the campus placements. Industry through the NASSCOM and other regulatory bodies has been changing the recruitment season between July and January. There has been no consistency from the industry on the recruitment season.

The students feel that June and July would be very early as they would not be prepared for the interviews. October and November months are examination months and after January, they are engaged with their project work and hence these months are less preferred. Most of the companies freeze on their campus recruitment budgets by June / July and hence the HR managers feel that after July will be an ideal period for the recruitments. The months between August and September were perceived to be the ideal months for recruitment by both the recruitment managers and the students.

Based on the above findings, the employers should frame a recruitment calendar which suits the students. This also would enable the recruitment managers to do branding engagements on campus to create the awareness among the students. Proper planning of recruitment schedule would help the recruitment managers to plan for the joining of the recruited students and also offer them internships / project work during their final semester.

There has always been a mismatch in the salary expectations of the entry level graduates, which were highlighted by the earlier studies. Though the salary levels in the IT services sector in India for the campus recruits has not changed for more than 5 years, the attractiveness (Joshi Kailash, 2008) of employment in IT sector has not decreased. Though the entry level salaries are less, the salary levels increase based on the experience they gain over the years. Since the supply of graduates for the IT sector has increased substantially over the years, the industry has not increased the entry level salaries. The entry level salary expectations of the students have increased due to the rise in the cost of education. They are also under pressure of repaying their educational loans (Mukta Kulkarni and Siddharth Nityanand, 2013).

Though the students consider a revision of entry level salaries, but salary has not been an influencing dimension in career choice (Gokuladas, 2010). The students have given more importance to their career growth and the opportunities that are given for the skill - development.

The recruiters should educate the students on the current industry trends and justify the salary levels to the students. Corporate should connect with the students (Eddy S.W.Ng, Ronald J.Burke, 2006), while on campus regularly to understand their perceptions.

Students need to do their research on various parameters before choosing a company in a campus recruitment process. The general complaint was that the entry level salaries offered by the software services companies were on the lower side. Based on the feedback from the HR managers, it is suggested that the students should lower the expectations on the entry level salaries as the present salary offered by the software services companies is based on the industry standards taking into consideration the demand and supply of the entry level graduates.

\section{References}

Bruce Basta, D' Archy Becker, P.Jane Staly, Richard S Sathe and Kate Mooney(2007), "Effective Campus Recruiting : Faculty perspective", CPA Journal,pp. 62-65 
Eddy S.W.Ng, Ronald J.Burke (2006), "The next generation at work - business students' views,values and job search strategy Implications for Universities and employers", Journal of Education + Training, Vol. 28 No. 7,pp.478 - 492

Gokuladas (2010),"Factors that influence first-career choice of undergraduate engineers in software services companies: A south Indian experience", Career Development International, Vol. 15 No. 2 pp. 144 - 165

Gokuladas (2010), "Technical and non-technical education and the employability of engineering graduates: an Indian case study", International Journal of Training and Development, Vol. 14 No.2,pp.130-143

Mukta Kulkarni, Siddharth Nithyanand (2013),"Social influence and Job choice decisions", Employee Relations, Vol. 35 Iss: (Date online 18/9/2012)

TimesJobs.com Bureau, "Train campus recruits early to build broader talent base"(Online) Available: http://articles.economictimes. indiatimes.com/2013-05-06/news/39065498_1_campus-recruitment-surveyed-organisations-timesjobs-com (May 6,2013) 